\title{
Analysis of the Construct Validity and Internal Consistency of the State-Trait Anxiety Inventory (STAI) State-Anxiety (S-Anxiety) Scale for Pregnant Women during Labor
}

\section{Análise da validade de constructo e consistência interna da escala de estado de ansiedade (E-Ansiedade) do inventário de ansiedade traço-estado (Idate) para gestantes em trabalho de parto}

\begin{abstract}
Alexandre Magno Delgado ${ }^{1}$ Alessandra da Boaviagem Freire ${ }^{2}$ Elaine Lima Silva Wanderley² Andrea Lemos ${ }^{2}$

1 Obstetrics Center, Residência Integrada Multiprofissional em Saúde, Hospital das Clínicas, Universidade Federal de Pernambuco, Recife, PE, Brazil

2 Post-Graduation Program in Physiotherapy, Universidade Federal de Pernambuco, Recife, PE, Brazil

Address for correspondence Andrea Lemos, Avenida Professor Moraes Rego, 1.235-Cidade Universitária, 50670-901 Recife (PE), Brasil

(e-mail: andrealemos4@gmail.com).
\end{abstract}

Rev Bras Ginecol Obstet 2016;38:531-537.

\begin{abstract}
Purpose To analyze the internal consistency and the construct validity of the State-Trait Anxiety Inventory (STAI) State-Anxiety (S-Anxiety) scale for pregnant women during labor. Method A study of measurement property including 150 pregnant women aged between 15 and 45 years old, during the first period of labor and with term pregnancies. The questionnaire used was the STAI S-Anxiety scale. In order to assess the internal consistency, Cronbach's $\alpha$ was calculated through an exploratory factor analysis. The correlation between the factors was calculated using the Pearson coefficient. The state of significance used for this analysis was 0.05 .

Results The STAI S-Anxiety scale used in the context of labor showed two factors represented as the absence (factor 1 ) and the presence of anxiety (factor 2); item 4 (“I regret it") did not show a representative value. Both factors showed high indications of Cronbach's $\alpha$, varying from 0.830 for factor 1 , and 0.723 for factor 2 . In the results of

Keywords

- labor

- anxiety

- pain

- factor analysis the Pearson coefficient between the two factors, a significant but weak correlation was observed $(r=-0.188 ; p=0.021)$.

Conclusion The STAI S-Anxiety scale used in pregnant women during labor presented appropriate values of internal consistency; however, item 3 did not show a significant factorial value. Therefore, this questionnaire must be applied cautiously and carefully without the use of the item 4 in the clinical practice and in researches about labor.
\end{abstract}

received

February 3, 2016

accepted

July 12, 2016

published online

March 11, 2016
DOI http://dx.doi.org/

10.1055/s-0036-1593894.

ISSN 0100-7203.
Copyright $(2016$ by Thieme-Revinter

Publicações Ltda, Rio de Janeiro, Brazil
License terms

(c) $(1) \$$ 


\section{Resumo}

\section{Palavras-chave \\ - trabalho de parto \\ - ansiedade \\ - dor \\ - análise fatorial}

\begin{abstract}
Objetivo Analisar a consistência interna e validade de constructo da escala de estado de ansiedade do Inventário de ansiedade traço-estado (Idate) para gestantes em trabalho de parto.

Métodos Trata-se de um estudo de propriedades de medida incluindo 150 gestantes com idade entre 15 e 45 anos, no primeiro período de trabalho de parto e com gestação a termo. O questionário utilizado foi a escala estado de ansiedade do Idate. Para a avaliação da consistência interna, o alfa de Cronbach foi calculado por meio da análise fatorial exploratória. A correlação dos fatores foi realizada por correlação de Pearson. $\mathrm{O}$ nível de significância adotado para esta análise foi de 0,05 .

Resultados Verificou-se que a escala estado do Idate no contexto de parto apresenta dois fatores, representados como ausência (fator 1) e presença de ansiedade (fator 2); o item 4 ("Estou arrependida") não apresentou valor representativo. Ambos os fatores apresentaram índices altos de alfa de Cronbach, variando entre 0,830 para o fator 1 e 0,723 para o fator 2 . Nos resultados da correlação de Pearson entre os dois fatores, foi observada uma correlação significativa, porém fraca $(r=-0,188 ; p=0,021)$.

Conclusões A escala de estado de ansiedade do Idate utilizada em gestantes durante o trabalho de parto apresentou valores de consistência interna adequados, porém o item 4 não apresentou valor fatorial representativo. Portanto, a utilização desse questionário na prática clínica e em pesquisas sobre o parto deve ser realizado sem a utilização do item 4 de maneira cautelosa e criteriosa.
\end{abstract}

\section{Introduction}

Labor is a unique event for each woman, and it is characterized by several physiological changes that are influenced by hormonal interactions, and by clinical, mechanical, social and psychological aspects. ${ }^{1,2}$ Within these psychological aspects, anxiety is the most common complaint, and it is generally associated to the fear of pain. ${ }^{3}$ About $80 \%$ of women have anxiety disorders during labor. ${ }^{4-7}$

The anxiety associated to labor activates the sympathetic branch of the autonomic and hypothalamic nervous systems. ${ }^{8}$ This activation stimulates the release of adrenaline, the stress hormone that directly counteracts oxytocin, which is responsible for the beginning and progression of labor. These changes may intensify the use of synthetic oxytocin, increase labor duration and the incidence of cesareans. ${ }^{9,10}$ Besides that, more bleeding during the labor and a delay in the beginning of lactation were observed in anxious women. $^{3}$

The existing studies in the area of obstetrics that have evaluated anxiety during labor used the state-trait anxiety inventory (STAI). This instrument is one of the most used in Brazil to evaluate anxiety in many contexts, from scientific research to clinical practice. ${ }^{11-14}$

The STAI was created by Spielberger et $\mathrm{al}^{15}$ in 1970 , and it was translated, adapted and validated for Brazil by Biaggio et $\mathrm{al}^{16}$ in 1977. It was originally created with the intent of providing a unique set of items that could be administrated by different instructions to access objective measures of anxiety state and trait. ${ }^{15}$ The anxiety state is defined as a transitory emotional state or human organism condition that is characterized by unpleasant feelings of tension and apprehension that are perceived consciously, and by an increase in autonomic nervous system activity. Another anxiety trait refers to a more stable aspect related to the individual propensity to deal with more or less anxiety throughout life. ${ }^{17}$

This questionnaire has already been validated for different patients, populations and languages. ${ }^{18-20}$ In these studies, the reliability evaluated by the $\alpha$ coefficient of Cronbach was high, which indicates that the items in the Portuguese version and the versions in other languages are highly homogenous. ${ }^{21}$ However, even though there are researches using this instrument for pregnant women in labor, there are no studies showing its validation in this context. Thus, this study aims to analyze the internal consistency and the construct validity of the STAI state anxiety (S-Anxiety) scale for pregnant women during labor.

\section{Method}

This study, which was conducted in the Obstetrics Center of the Hospital das Clínicas da Universidade Federal de Pernambuco (UFPE), Brazil, evaluated the construct validity and internal consistency of the STAI S-Anxiety scale for pregnant women in labor.

For convenience, the volunteers were recruited in a sequential manner during the period of February to August 2015. The interviews lasted between 5 and 10 minutes, and they were conducted while the pregnant women did not have pain or some discomfort that hindered them from responding. When the pregnant women mentioned pain or discomfort, the interviews were interrupted and resumed when the symptoms were reduced. Before 
inclusion, all participants were told about the objectives, risks and benefits of the research, and those who desired to join signed a written informed consent form or a written informed assent form, for girls under 18 years old.

The criteria used for inclusion were parturients in their first labor, with ages ranging from 15 to 45 years old, with low-risk pregnancies. The exclusion criteria went as follows: twin pregnancy or dead fetus, parturients with clinical instability, and those who did not understand the items in the questionnaire.

The sample calculation was done considering seven subjects $^{22}$ per item of the questionnaire. Since the STAI has 20 items, the final sample comprised 150 pregnant women in labor.

For the data collection, two instruments were used: the first was a form developed specifically for this study, with sociodemographic (age, marital status, educational level, family income, occupation and origin) and obstetric data (number of deliveries, gestational age). The second instrument was the STAI S-Anxiety scale, which was applied through interviews by the previously trained physiotherapy resident of UFPE's Residência Integrada Multiprofissional em Saúde.

The STAI is composed of 40 statements, 20 for trait anxiety (T-Anxiety) evaluation, and 20 for state anxiety (S-Anxiety) evaluation. In this study, only the STAI S-Anxiety scale was used. According to this inventory, the SAnxiety scale requires that the participant describes how he or she feels "now, at the present moment" in relation to the 20 items presented in a Likert scale of 4 points: 1Absolutely not; 2- A little; 3- Much; 4- Very Much. Its final score varies from 20 to 80 , and the higher the values, the greater the anxiety level. ${ }^{15}$
The analysis of the data was performed using the Statistical Package for Social Sciences (SPSS) software, version 18 for Windows. For the sample characterization, the mean and standard deviation (SD) of the variables age and gestational age were calculated. In the descriptive analysis, the data was presented in distribution tables of the absolute and relative frequencies.

Factor analysis was used because it is the most appropriate to test the permanence of the theoretical model of a scale's original version in another culture or population. The verification of the conditions to perform this analysis was performed through the calculation of the sample adequacy index of Kaiser-Meyer-Olkin (KMO). After that, the exploratory factor analysis method was applied to verify both the factors of the data through the scree plot according to the theory of Cattel ${ }^{23}$, and the definition of the number of factors to be properly retained and extracted. Once the factor analysis was done, Cronbach's $\alpha$ coefficients were computed to verify the internal consistency of the extracted factors. At the end, the Pearson's correlation was applied to verify the existence of a relationship between the factors, and to analyze the correlation force between the measures of the two factors that were found. The level of significance adopted for this analysis was of 0.05 .

This study was performed according to the recommendations of the Brazilian Minister of Health's Resolution n. 466/12, and it started after the approval of the UFPE Ethics Committee for Research, under the number CAAE 38761514.0.0000.5208.

\section{Results}

During data collection, 500 pregnant women were evaluated sequentially and by convenience for eligibility criteria, and 150 were eligible and included. Exclusions occurred mainly

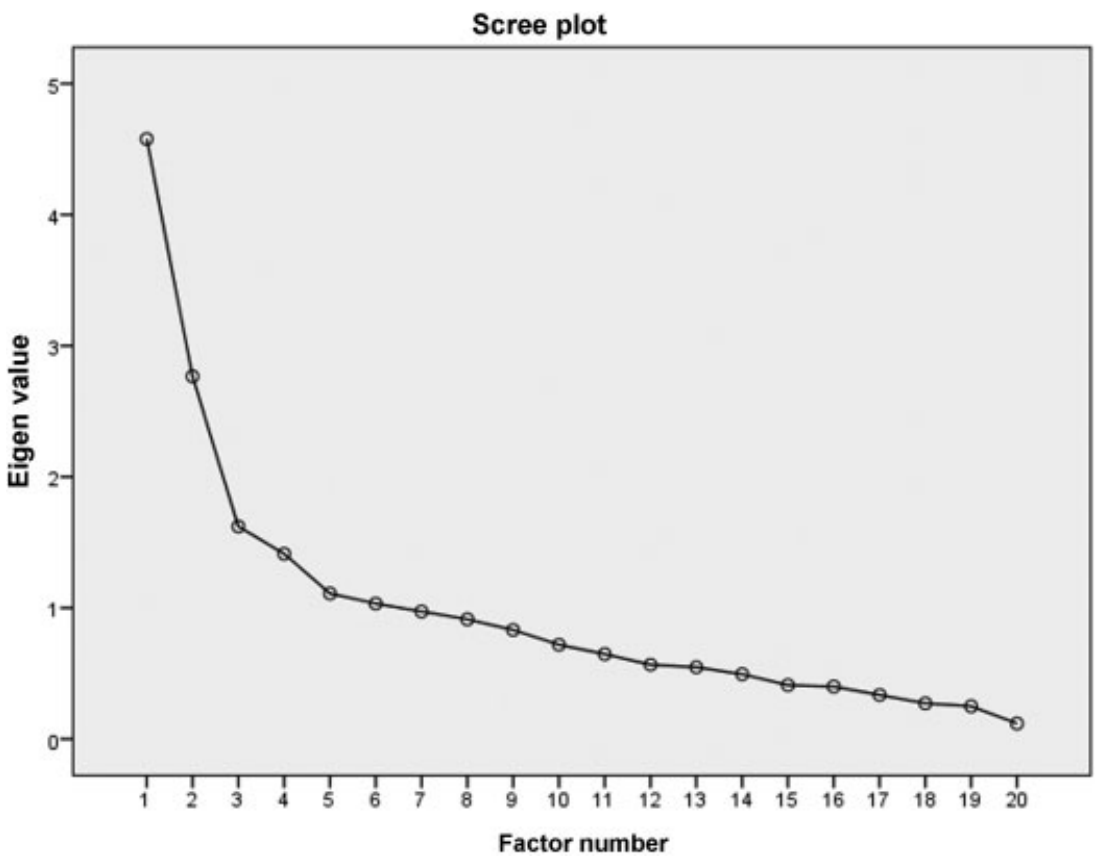

Fig. 1 Scree plot analysis of the factors. 
Table 1 Characteristics of the participants

\begin{tabular}{|c|c|}
\hline Characteristics & Parturients $n=150$ \\
\hline \multicolumn{2}{|l|}{ Age (years) } \\
\hline Variation & $15-40$ \\
\hline Mean \pm SD & $24.61 \pm 6.210$ \\
\hline \multicolumn{2}{|l|}{ Gestational age (week) } \\
\hline Variation & $37-41$ \\
\hline Mean \pm SD & $39.18 \pm 1.14$ \\
\hline \multicolumn{2}{|l|}{ Number of deliveries $\mathrm{n}(\%)$} \\
\hline Nulliparous & $60(40.0 \%)$ \\
\hline Primiparous & $20(13.3 \%)$ \\
\hline Multiparous & $70(46.7 \%)$ \\
\hline \multicolumn{2}{|l|}{ Marital status n (\%) } \\
\hline Single & $32(21.3 \%)$ \\
\hline Married & $42(28 \%)$ \\
\hline Widow & $1(0.7 \%)$ \\
\hline Consensual union & $75(50 \%)$ \\
\hline \multicolumn{2}{|l|}{ Educational level $n(\%)$} \\
\hline $1-3$ years & $6(4 \%)$ \\
\hline $4-7$ years & $30(20 \%)$ \\
\hline $8-11$ years & $54(36 \%)$ \\
\hline More than 12 years & $60(40 \%)$ \\
\hline \multicolumn{2}{|l|}{ Per capita income $n(\%)$} \\
\hline$<1 \mathrm{MW}$ & $65(43.3 \%)$ \\
\hline $1-3 \mathrm{MW}$ & $81(54 \%)$ \\
\hline 4-6 MW & $4(2.7 \%)$ \\
\hline \multicolumn{2}{|l|}{ Origin $n(\%)$} \\
\hline Metropolitan region & $101(67.3 \%)$ \\
\hline Pernambuco countryside & $45(30 \%)$ \\
\hline Other regions & $4(2.7 \%)$ \\
\hline \multicolumn{2}{|l|}{ Occupation $n(\%)$} \\
\hline Housewife & $79(52.7 \%)$ \\
\hline Others & $71(47.3 \%)$ \\
\hline
\end{tabular}

Abbreviations: MW, minimum wage; SD, standard deviation.

due to high-risk pregnancies and clinical instability. The average age of the pregnant women was 24.61 years (SD $=6.21)$ and the average gestational age was 39.18 weeks $(\mathrm{SD}=1.14)$. About the anxiety level score assessed by STAI, most of the parturients showed a moderate anxiety level (66.7\%), followed by high anxiety (20\%) and low anxiety (13.3\%).

Less than half of the pregnant women included were nulliparous (40\%). Most were in a stable consensual union (50\%); had 12 years or more of education (40\%); a per capita income smaller than one minimum wage (43.3\%); lived in the metropolitan region (67.3\%); and were housewives (52.7\%, against $47.3 \%$ who had a paid job) (-Table 1 ).
Table 2 Factor analysis of the two factors

\begin{tabular}{|l|l|l|}
\hline Items & Factor 1 & Factor 2 \\
\hline 1. I feel calm & -0.373 & \\
\hline 2. I feel safe & & 0.391 \\
\hline 3. I feel tense & 0.676 & \\
\hline 5. I feel at ease & & 0.520 \\
\hline 6. I feel disturbed & 0.332 & \\
\hline $\begin{array}{l}\text { 7. I am worried about } \\
\text { possible misfortunes }\end{array}$ & 0.539 & \\
\hline 8. I feel rested & & 0.461 \\
\hline 9. I feel anxious & 0.339 & \\
\hline 10. I feel 'at home' & & 0.546 \\
\hline 11. I feel confident & & 0.453 \\
\hline 12. I feel nervous & 0.655 & \\
\hline 13. I am busy & 0.803 & \\
\hline 14. I feel like a nervous wreck & 0.747 & \\
\hline 15. I am relaxed & & 0.443 \\
\hline 16. I am pleased & & 0.526 \\
\hline 17. I am worried & 0.609 & \\
\hline $\begin{array}{l}\text { 18. I am super excited } \\
\text { and confused }\end{array}$ & 0.648 & \\
\hline 19. I am happy & & 0.390 \\
\hline 20. I feel good & & \\
\hline
\end{tabular}

* Item 4 (“I regret it”) not included.

The index found when verifying the conditions for performing the exploratory factor analysis by calculating the sample adequacy index of KMO was of 0.730 , which indicated the existence of enough correlations between the variables of the factor analysis. ${ }^{22}$ By analyzing the scree plot in - Fig. 1 according to Cattel's theory, ${ }^{23}$ we observed that the first two factors could be classified as the two main factors that best represent the composition of the instrument in question.

Based on this result, the extraction of two factors was imposed by the method of the main axis and oblimin rotation, due to the expectation of obtaining the significant correlations between the two factors. From the 20 items of S-Anxiety, 19 of them were used: item 4 ("I regret it") was not considered, as it does not have a representative load greater than 0.3 . The remaining 19 items were divided into 2 factors, with factor 1 representing the semantic content that expresses the presence of anxiety, tension or worry (presence of anxiety), which is represented by the items $1,2,5,8$, $10,11,15,16,19$ and 20 . Factor 2 had a semantic content that expresses feelings of well-being or safety (absence of anxiety), and it is represented by the items $3,6,7,9,12,13,14,17$ and 18.

- Table 2 presents the factor load distribution of all items from STAI S-Anxiety scale, except for item 4 . We found factor loads that vary between 0.90 and 0.33 for factor 1 , and 
between 0.54 and 0.39 for factor 2 , which are values considered appropriate. ${ }^{22}$

In the results of the Pearson correlation between the two factors, a significant but weak correlation $(r=-0.188$; $p=0.021$ ) was observed. In the analysis of the Cronbach's $\alpha$ for factors 1 and 2, high indexes of consistency, varying between 0.830 for factor 1 and 0.723 for factor 2 were revealed.

\section{Discussion}

The results achieved by this study show that the STAI SAnxiety scale presented a good internal consistency, representing the evaluated construct that should be used for pregnant women in labor, and, in this context, two factors were found. The first factor, composed by 10 items, shows the semantic content that expresses the presence of anxiety, tension or worry, and the second factor was composed by a content that expresses feelings of absence of anxiety or wellbeing, represented by 9 items. Item 4 ("I regret it") was removed, as it does not have a representative load, so the questionnaire had a total of 19 items.

This kind of evaluation is important to identify if the STAI S-Anxiety scale, the most used in researches about maternal anxiety during childbirth, shows a good internal consistency and can, therefore, represent the evaluated construct in the scenario of childbirth. ${ }^{13,24,25}$ This kind of analysis (factor analysis) is one of the most commonly used statistical procedures in the development, evaluation and refining of psychometrical instruments. ${ }^{26}$ It is defined as a set of multivariate techniques that aims to find the subjacent structure in a data matrix and determine the number and nature of the latent variables (factors) that best represent a set of observed variables. ${ }^{27}$

The results of this study indicate high levels of internal consistency in the STAI S-Anxiety scale. In the Cronbach's $\alpha$ analysis, values of 0.830 for factor 1 and of 0.723 for factor 2 were found; these results are above the ones considered as acceptable within a scale of this kind. ${ }^{28,29}$ When an instrument has more than one dimension/scale, the $\alpha$ for each scale should be evaluated separately. In the correlation between two factors, a significant but weak correlation was observed. When high scores were observed in a factor, they tended to be accompanied by low scores in the other factor. ${ }^{30}$

The Cronbach's alphas found in this study confirm those results previously stated in the Brazilian literature that used the STAI S-Anxiety scale with samples of students from high school (0.87) and college (0.89), military (0.82) and selective process participants $(0.79){ }^{21,31,32}$

The two factors found for the STAI S-Anxiety scale for pregnant women in labor were classified as "presence of anxiety" and "absence of anxiety." In Brazil, the studies conducted with the purpose of understanding the factorial structure of STAI that analyzed the validity of the trait of anxiety also found two factors. ${ }^{21,31,32} \mathrm{~A}$ study with a sample of students in a selective process also showed, through factor analysis, that the STAI T-Anxiety scale is formed by two factors that were classified as "presence of anxiety" and "absence of anxiety"31. Another study with a sample of Brazilian students demonstrated that one factor was related to anxiety, and the other, to depression. ${ }^{21}$ However, a study using three Brazilian samples (university students and high school students and military in evaluation process) indicated different factor structures according to the studied sample. While the sample of university students and high school students showed, respectively, a factor structure favorable to the interpretation of an anxiety component and another to depression, the military sample favored a suggestive interpretation of the presence or absence of anxiety. ${ }^{32}$

Item 4 ("I regret it") of the STAI S-Anxiety scale did not have a representative statistical value, and it was excluded from the analysis. This mathematical result is a clinical reflex of the circumstances of the measurement of anxiety, or the moment of childbirth. Regret is not a common feeling during labor. It goes against the experience of parturition, represented as a relevant and unique event in the life of women, marked by transformation, even though the process can be extremely painful. ${ }^{33}$ In an integrated review about women's perception of the experience of childbirth, ${ }^{34}$ the moment was described as a unique and important experience that women expect to live in a physiological, natural and healthy way, for them and their newborns. ${ }^{35,36}$ Women report this moment as exciting, one of personal growth, for the creation of a new identity. The status of being a mother ${ }^{37}$ is surrounded by positive feelings, described as joy, happiness and realization. ${ }^{38}$

The distribution of the factor loads of all items of STAI SAnxiety, except for item 4, presented results greater than 0.3, which were considered appropriate. ${ }^{39}$ Factor 1 presented values ranging from 0.80 to 0.33 , and factor 2 , between 0.54 and 0.39 . Only item 1 ("I feel calm") of factor 1 ("presence of anxiety") showed a negative value. In other words, this item is the only one going on the opposite direction as the others. This item is related to feelings that are opposed to the others (like tension, disturbance, worry and anxiety), resulting in different scores.

It is important to mention that in this study the application of the questionnaire occurred in the interview format, and the favorable results regarding the internal consistency reflect that this mode of application is appropriate. The STAI was created as a self-administered ${ }^{15}$ questionnaire; however, in the context of childbirth, it is difficult for the subjects to self-administer the questionnaire, as childbirth is a moment that does not allow much concentration for reading, interpreting and for the assimilation of the answers.

Most parturients who joined this research were multiparous with low-risk pregnancies. This obstetric scenario could interfere in the development of anxiety during labor. ${ }^{40}$ Item 4 ("I regret it") did not have a representative value in this kind of studied population, but it could have some influence if the women had high-risk pregnancies, presenting a significant factor load value. The existence of some sort of gestational risk favors a differentiated state for the pregnant woman when compared with the ones who do not show any evidence of possible complications. ${ }^{41,42}$ 
In this research, some potential limitations can be considered, like the lack of a reliability test and intra and interrater error measurements, once it is not possible to repeat the test with the same volunteer and wait for similar results, as the progression of labor results in situations with different characteristics at each moment. Another limitation is the interpretability of the score without item 4 . With the removal of an item, there are changes in the total score, and this may affect the interpretability of the instrument, that is, the way of making qualitative inferences to the quantitative scores.

The STAI S-Anxiety scale uses a score of 4 points in each item to verify the intensity of anxiety, resulting in a variation of 20 to 80 points. Subjects are categorized as having low anxiety (20 to 40 points), medium anxiety (41 to 60 points) and high anxiety (61 to 80 points). With the removal of item 4 , this variation changes to 16 to 74 points.

Despite the limitations above mentioned, it is important to highlight that, as far as we know, this is the first study that evaluated the validity of construct and internal consistency of the STAI S-Anxiety scale in pregnant women during labor.

\section{Conclusion}

The findings of the present study show that the use of the STAI S-Anxiety scale in pregnant women during labor has two factors, both with appropriate values of internal consistency, but item 4 ("I regret it") did not have a representative factor value. We suggest that future studies evaluate other properties of measure, as reliability and inter-rater error measurements and validity, as well as the interpretability, without item 4, in low- and high-risk pregnant women. Thus, this questionnaire should be applied without item 4 in a cautious and judicious manner in the clinical practice and in researches about childbirth.

\section{Note}

We report no conflicts of interest.

\section{References}

1 Brüggemann OM, Parpinelli MA, Osis MJD. Evidence on support during labor and delivery: a literature review. Cad Saude Publica 2005;21(5):1316-1327

2 Manozi SR, de Carvalho EC, dos Santos CB. Clinical validation of the nursing diagnosis labor pain. Rev Lat Am Enfermagem 2013; 21:88-96

3 Spice K, Jones SL, Hadjistavropoulos HD, Kowalyk K, Stewart SH. Prenatal fear of childbirth and anxiety sensitivity. J Psychosom Obstet Gynaecol 2009;30(3):168-174

4 Holm L, Fitzmaurice L. Emergency department waiting room stress: can music or aromatherapy improve anxiety scores? Pediatr Emerg Care 2008;24(12):836-838

5 Alipour Z, Lamyian M, Hajizadeh E. Anxiety and fear of childbirth as predictors of postnatal depression in nulliparous women. Women Birth 2012;25(3):e37-e43

6 Hodnett ED. Pain and women's satisfaction with the experience of childbirth: a systematic review. Am J Obstet Gynecol 2002;186(5, Suppl Nature )S160-S172
7 Landolt AS, Milling LS. The efficacy of hypnosis as an intervention for labor and delivery pain: a comprehensive methodological review. Clin Psychol Rev 2011;31(6):1022-1031

8 Arun CP. Fight or flight, forbearance and fortitude: the spectrum of actions of the catecholamines and their cousins. Ann N Y Acad Sci 2004;1018:137-140

9 Balaskas J. Parto ativo: guia prático para o parto natural. São Paulo Ground1993

10 Busch V, Magerl W, Kern U, Haas J, Hajak G, Eichhammer P. The effect of deep and slow breathing on pain perception, autonomic activity, and mood processing-an experimental study. Pain Med 2012;13(2):215-228

11 Azevedo PBD, Kaipper MB, Fumegalli EB, Chachamovich E, Caumo W. Proposta de simplificação do inventário de ansiedade traçoestado (IDATE) através da análise da psicométrica clássica e modelo de Rasch. Rev HCPA. 2008;28(Suppl):304-305

12 Grimstad H, Schei B, Backe B, Jacobsen G. Anxiety, physical abuse, and low birth weight. Scand J Public Health 1999; 27(4):296-300

13 Almeida NAM, de Sousa JT, Bachion MM, Silveira NdeA. The use of respiration and relaxation techniques for pain and anxiety relief in the parturition process. Rev Lat Am Enfermagem 2005;13(1): 52-58

14 Baptista MN, Baptista ASD, Torres ECR. Associação entre suporte social, depressão e ansiedade em gestantes. Psic. 2006;7(1): 39-48

15 Spielberger CD, Gorsuch RL, Lushene RE. STAI: manual for the State-Trait Anxiety Invetory. Palo Alto: Consulting Psychologists; 1970

16 Biaggio AMB, Natalício L, Spielberger CD. Desenvolvimento da forma experimental em português do Inventário de Ansiedade Traço-Estado (IDATE) de Spielberger. Arq Bras Psicol Apl. 1977; 29(3):31-44

17 Cattell RB, Scheier IH. The meaning and measurement of neuroticism and anxiety. New York: Ronald Press; 1961

18 Gorenstein C, Andrade L. Validation of a Portuguese version of the Beck Depression Inventory and the State-Trait Anxiety Inventory in Brazilian subjects. Braz J Med Biol Res 1996;29(4):453-457

19 Gorenstein C, Pompéia S, Andrade L. Scores of Brazilian University students on the Beck Depression and the State Trait Anxiety Inventories. Psychol Rep 1995;77(2):635-641

20 Gorenstein C, Andrade L, Vieira Filho AH, Tung TC, Artes R. Psychometric properties of the Portuguese version of the Beck Depression Inventory on Brazilian college students. J Clin Psychol 1999;55(5):553-562

21 Andrade L, Gorenstein C, Vieira Filho AH, Tung TC, Artes R. Psychometric properties of the Portuguese version of the StateTrait Anxiety Inventory applied to college students: factor analysis and relation to the Beck Depression Inventory. Braz J Med Biol Res 2001;34(3):367-374

22 Tabachnick BG, Fidell LS. Using multivariate statistics. 4th ed. Boston: Allyn and Bacon; 2001

23 Cattell RB. The scree test for the number of factors. Multivariate Behav Res 1966;1(1):245-276

24 Bõing I, Sperandio FF, Santos GM. Uso de técnica respiratória para analgesia no parto. Femina 2007;35(1):41-46

25 Namazi M, Amir Ali Akbari S, Mojab F, Talebi A, Alavi Majd H, Jannesari S. Aromatherapy with citrus aurantium oil and anxiety during the first stage of labor. Iran Red Crescent Med J 2014;16(6): e18371

26 Floyd FJ, Widaman KF. Factor analysis in the development and refinement of clinical assessment instruments. Psychological Assessment 1995;7(3):286-299

27 Brown TA. Confirmatory factor analysis for applied research. New York: Guilford; 2006

28 Carmines EG, Zeller RA. Reliability and validity assessment. Newbury Park: Sage; 1979 
29 Cronbach LJ. Coefficient alpha and the internal structure of tests. Psychometrika 1951;16(3):297-334

30 Terwee CB, Mokkink LB, Knol DL, Ostelo RW, Bouter LM, de Vet HC. Rating the methodological quality in systematic reviews of studies on measurement properties: a scoring system for the COSMIN checklist. Qual Life Res 2012;21(4):651-657

31 Pasquali L, Pinelli Júnior B, Solha AC. Contribuição à validação e normalização da escala de ansiedade traço-estado do IDATE. Psicol, Teor Pesq 1994;10(3):411-420

32 Fioravanti ACM, Santos LF, Maissonette S, Cruz APM, LandeiraFernandez J. Avaliação da estrutura fatorial da escala de ansiedade-traço do IDATE. Aval Psicol 2006;5(2):217-224

33 Tedesco RP, Maia Filho NL, Mathias L, et al. [Primigravid expectations about the delivery method and the causal factors for their choice]. Rev Bras Ginecol Obstet 2004;26(10):791-798 Portuguese

34 Velho MB, Santos EKA, Brüggemann OM, Camargo BV. Vivência do parto normal ou cesáreo: revisão integrativa sobre a percepção de mulheres. Texto Contexto Enferm 2012;21(2):458-466

35 Miranda DB, Bortolon FCS, Matão MEL, Campos PHF. Parto normal e cesária: representações de mulheres que vivenciaram as duas experiências. Rev Eletr Enferm. 2008;10(2): $337-346$
36 Gama AdeS, Giffin KM, Angulo-Tuesta A, Barbosa GP, d'Orsi E. Women's representations and experiences with vaginal and cesarean delivery in public and private maternity hospitals. Cad Saude Publica 2009;25(11):2480-2488

37 Callister LC, Vehvilainen-Julkunen K, Lauri S. Giving birth. Perceptions of Finnish childbearing women. MCN Am J Matern Child Nurs 2001;26(1):28-32

38 McCallum C, dos Reis AP. Re-signifying pain, overcoming loneliness: childbirth experiences among working-class adolescents in a public maternity hospital in Salvador, Bahia, Brazil. Cad Saude Publica 2006;22(7):1483-1491

39 Hair JF Jr, Black WC, Babin BJ, Anderson RE, Tatham RL. Multivariate data analysis. 6th ed.Upper Saddle River: Pearson Prentice Hall; 2006

40 Correia LL, Linhares MBM. Maternal anxiety in the pre- and postnatal period: a literature review. Rev Lat Am Enfermagem 2007;15(4):677-683

41 Byatt N, Hicks-Courant K, Davidson A, et al. Depression and anxiety among high-risk obstetric inpatients. Gen Hosp Psychiatry 2014;36(6):644-649

42 Lynch CE, Magann EF, Barringer SN, et al. Pet therapy program for antepartum high-risk pregnancies: a pilot study. J Perinatol 2014; 34(11):816-818 